\title{
The relation between enamel defects in deciduous teeth, nutritional status and the development of basic skills in children with small for gestational age
}

\author{
Katina Miguna*, Williyanti Soewondo*, Roosje Rosita Oewen*, Eddy Fadiyana* \\ *Department of Pedodontics Faculty of Dentistry Universitas Padjadjaran
}

\section{ABSTRACT}

Introduction: Small for Gestational Age (SGA) babies are those whose birth weight are less than 2 SD or below the 10th percentile curve of Lubchenco intrauterine growth and development. The cause of SGA is due to an Intra-uterine growth restriction (IUGR). IUGR inhibits the development of various organs, including the enamel of deciduous teeth and the central nervous system (CNS). The research aims to analyzed correlation between enamel defects in deciduous teeth, nutritional status and the development of basic skills in children with SGA. Methods: A total of 28 SGA children aged between 3-6 years were obtained from Hasan Sadikin Hospital. The sample comprised of 20 boys and 8 girls to be studied for tooth enamel defects in deciduous teeth, weight, height and development basic capabilities. Study design was descriptive and analytical, with cross-sectional study. Scoring modification Developmental Defect of Enamel (DDE) of the FDI was used to assess the enamel defects in deciduous teeth. Enamel Defect Score (EDS) was calculated according to the Willyanti's formula. The nutritional status was measured by measuring height, weight, and age and converted to the diagram of Body Mass Index (BMI) / Age of the WHO Child Growth Standards. While the development of SGA children basic skills was measured using pre- screening questionnaire development (KPSP). To determine the linkage between enamel defects in deciduous teeth and nutritional status with basic skills development in SGA children, the non-parametric statistical analysis of Kendall's Coefficient of Concordance was performed. Results: Statistical test results showed that Kendall's Coefficient of Concordance $(\mathrm{W})=1.00$ is statistically significant with Chisquare value $=56.00$ with $p$ (value) $<0.01$. Conclusion: There is a significant relationship between EDS and nutritional status with the SGA children development of basic skills as well as the development of the child's ability.

Keywords: Enamel defects, deciduous teeth, nutritional status, children basic skills development, SGA.

\section{INTRODUCTION}

Small Baby Pregnancy (KMK) is an infant with birth weight below grade 2 (standard deviation) or below percentile 10 Growth Curve and Development of Intrauterine Lubchenco. Infant KMK can be born less than month (premature / less than 37 weeks' gestation), mature or maturity month. $1,2,3,470 \%$ of low birth weight babies (BBLR) are babies of KMK. According to WHO (1961), LBW is an infant born with a birth weight of less than 2500 grams. $^{5}$

The birth of KMK baby in Dr. Cipto Mangunkusumo hospital recorded to reach $4.42 \%$ (in 1999), while 123 out of 2,804 births in Perjan Hasan Sadikin Hospital is a KMK baby. This figure 
shows a fairly high percentage, ie $7.6-10 \%$ of all births in Hasan Sadikin Hospital in 2005.6,7

Causes of KMK infant due to Intra Uterine Growth Restriction (IUGR) inhibition / inhibition of growth. In Indonesia, the term IUGR is called Fetal Growth Hampered (PJT). IUGR-causing factors are mechanical trauma, toxins / chemicals, endocrine factors, radiation, infection, stress, immunity, embryonic anoxia and maternal nutrition during pregnancy. ${ }^{8}$ Nutrition is related to socio-economic situation, and according to statistical data the percentage of Indonesian population below the poverty line in 1980-1989 for urban area is 20\%, while for rural area is $16 \%{ }^{8.9}$ Low socio-economic conditions will have an impact on the lack of health care and lack of good nutrition for the health of pregnant women.

Intra Uterine Growth Restriction will affect the development of the fetus and will lead to developmental defects of various organs, including the teeth and brain. Prenatal period is a critical moment for the formation of teeth, especially the deciduous tooth. The process of developing primary teeth begins between weeks 6-7 in the embryonic period. ${ }^{10,11,12,13,14}$ IUGR will disrupt the process of growth and development of primary teeth. Disorders in the formation of deciduous teeth will result in the defect of enamel of primary teeth. The extent of enamel dental defects depends on the intensity, duration and occurrence. Email is formed only once and does not undergo remodeling, so the damage is permanent. This condition will interfere with the function of mastication and esthetics. ${ }^{10,13}$ The incidence of defect enamel KMK child's first tooth equal to $86,93 \%$ while in SMK child (According Pregnancy) equal to $23,08 \%$, hence incidence of tooth enamel defects in KMK child compared to SMK child is almost four times bigger. ${ }^{7}$

IUGR will interfere with the growth of the fetal central nervous system, as brain growth occurs on the 16th day of intra uterine and continues until the first years of life, so that by the age of 6 years growth has reached almost $90 \%$ of adult brains. ${ }^{15}$ Hence, which occurs in the intrauterine period will cause damage to the brain structure, especially when growth disorders occur in the stage of brain growth (hyperplasia). The toxic period of growth of nerve cells is the third trimester of pregnancy until about 2 years after birth. Disorders of this period will cause the number of brain cells to decrease, which will affect the structure and function of the brain that will affect the development of basic ability of children. This can be indicated by the development of language, personal social, motorist motion fine and rough motor. ${ }^{8}$

The development of children's basic ability is influenced by innate factors (genetic, congenital abnormalities, hormonal), and also influenced by the environment (quality and quantity of nutrients, chronic diseases, emotional disturbances, stimulation). A good environment will allow the acceleration of the growth rate, whereas a poor environment will inhibit it. ${ }^{16}$ Food sufficiency in both quality and quantity is essential for normal growth. Babies must get nutritious food. Babies / children who get good nutrition, will experience optimal growth and development. While severe malnutrition, will cause these children to experience a loss of opportunity (irreversible loss of opportunity), which should not happen if from the beginning the child gets adequate nutrition. ${ }^{8}$

Acceleration of growth rate usually occurs before the age of 2 years and can include acceleration of weight gain, acceleration of body elevation also accelerate the addition of head circumference. Weight gain, body elevation, and head circumference addition can be an indicator of achievement of growth. ${ }^{16}$ The purpose of measuring Body Mass Index (BMI) / age is to determine the nutritional status of the child. Growth correlates with growth. As growth progresses rapidly, such developments, there will be mental enhancement, memory, reasoning power, association and others. ${ }^{8}$ The research aims to find out the correlation between enamel defects in deciduous teeth , nutritional status and the development of basic skills in children with Small for Gestational Age (SGA).

\section{METHODS}

Subjects in this study were children with a history of Small Pregnancy / KMK who were born in Dr. Hasan Sadikin Bandung Hospital in 20042007 and at the time of the study aged 3-6 years.

The design of this study is an analytic descriptive study, with a cross-sectional study design. Sample size given is all children who 
meet the criteria of KMK child who was born in Dr. Hasan Sadikin Bandung Hospital and now aged 3-6 years. The child's age is calculated by the date of examination minus the date of birth, then recorded in lunar units. KMK infants are babies born with birth weight below the 10th percentile on the growth curve and intra uterine development of Lubchenco. Deciduous tooth enamel defects appear as hypoplasia and hypocalcification. Hypoplasia, if visible pits, grooves, holes on the enamel surface of the tooth.

Hypocalcified if visible tooth opaque / not smooth, not translucent. If there is any hypoplasia and hypocalcification, then the term used is hypoplasia. The severity criteria of dental root defect severity was measured by DDE score according to FDI modification. Dental examination is performed by mouth, explorer, and probe with sufficient illumination. All surfaces of the tooth are cleaned, dried with cotton roll then examined and recording the first dental defect by scaling DDE (developmental defect of enamel) modification according to FDI to determine the severity of the defect.17 Modification of DDE Index, with scores: 1 = Normal: smooth email, milky white color; 2 = Hypocalcification - Opacity: the presence of opaque white color is opaque, or brown, yellow; 3 = Email-pit hyperlasia: Quantitatively there are defects, pits and grooves on some teeth; 4 $=$ Hypoplasia email-difuse: visible defects, there are vertical grooves that may also be irregular; 5 = Email-linear hypoplasia type: horizontal groove; 6 = enamel enameled hypoplasia: lost most emails at multiple locations. ${ }^{17}$ Enamel Defect Score (EDS) counted by the formula:

$$
\mathrm{EDS}=\frac{\text { EHP } x \text { number of teeth with defects } x 10}{\text { number of teeth at risk }}
$$

EDS categorized by Willyanti ${ }^{7}$ In order to study the basic skills of KMK children using PreScreening Questionnaire (KPSP), each child was assessed using a questionnaire appropriate to the child's age in months.

Body weight index (BMI) is the result of division of body weight (in kilograms) with the square height of body (in meters), the result is then plotted with BMI diagram / age from WHO Child Growth Standard to get the category of nutritional status. In order to know to what extent the correlation of enamel dental defect and nutritional status with the development of the basic ability of KMK children, non parametric statistical analysis used is Kendall Coefficient Of Concordance.

\section{RESULTS}

The variable of child's ability development and nutritional status are assessed by the nominal

Tabel 1. DDE score category

\begin{tabular}{cc}
\hline DDE score & Category \\
\hline 0 & Normal \\
$<12$ & Lightweight \\
$\geq 12$ & Heavyweight \\
\hline
\end{tabular}

Table 2. table of EDS, nutritional status, and basic skill development

\begin{tabular}{cclc}
\hline No & Eds & Nutritional status & Basic skill development \\
\hline 1 & 6,00 & underweight & $\mathrm{P}$ \\
2 & 8,00 & normal & $\mathrm{S}$ \\
3 & 8,00 & normal & $\mathrm{S}$ \\
4 & 8,00 & normal & $\mathrm{S}$ \\
5 & 9,00 & normal & $\mathrm{S}$ \\
6 & 10,00 & normal & $\mathrm{S}$ \\
7 & 10,00 & underweight & $\mathrm{P}$ \\
8 & 13,00 & normal & $\mathrm{S}$ \\
9 & 13,00 & underweight & $\mathrm{P}$ \\
10 & 13,00 & normal & $\mathrm{S}$ \\
11 & 13,33 & underweight & $\mathrm{P}$ \\
12 & 13,50 & normal & $\mathrm{S}$ \\
13 & 14,00 & normal & $\mathrm{S}$ \\
14 & 15,00 & underweight & $\mathrm{P}$ \\
15 & 15,00 & normal & $\mathrm{S}$ \\
16 & 15,00 & normal & $\mathrm{S}$ \\
17 & 16,00 & normal & $\mathrm{S}$ \\
18 & 18,00 & normal & $\mathrm{S}$ \\
19 & 18,30 & underweight & $\mathrm{S}$ \\
20 & 18.75 & underweight \\
21 & 20,00 & normal & $\mathrm{S}$ \\
22 & 20,00 & normal \\
23 & 20,00 & normal & $\mathrm{P}$ \\
24 & 22,00 & normal \\
25 & 22,00 & normal \\
26 & 23,30 & normal & $\mathrm{S}$ \\
27 & 26,00 & normal & $\mathrm{S}$ \\
\hline & 60,00 & normal & $\mathrm{S}$ \\
& &
\end{tabular}


(binary) measurement scale, whereas EDS is assessed based on the score of the sub-variable assessment of EDS. The results of research for all research variables are shown in Table 2.

Table 2 shows that KMK children who has any deciduous enamel cage of lightweight (EDS <12) are 7 children. Judging from the nutritional status and the development of basic ability, as many as 2 children (28.57\%) with thin nutritional status experienced the development of basic abilities that deviate $(P)$, while 5 children (71.42\%) with normal nutritional status was experiencing development ability a good base (S).

A total of $21 \mathrm{KMK}$ children who had severe cervical enamel defects (EDS $\geq 12)$, were seen in children with nutritional status, 5 children $(23.81 \%)$ had a deviant development of basic ability $(P)$. While 16 children (76.19\%) had EDS weight category
(EDS $\geq 12$ ) with normal nutritional status, the development of basic ability was also good (S).

The development of basic skills will be good, if normal nutritional status, on the contrary the development of basic skills will diverge when the nutritional status of skinny. In conclusion, nutritional status is very important for the development of basic capabilities of KMK children. Based on the data from Table 2, it is necessary to know how the relationship between the three research variables is between EDS, nutritional status and the development of KMK child ability whose data is shown in Table 3.

The statistical test with Chi-square test to see correlation between EDS and nutritional status with the development of KMK child's basic ability is done by calculating the magnitude $\mathrm{W}$ with formula (2) and Chi-square value with the formula

Table 3. EDS score, nutritional status, and children ability development KMK $(n=28)$

\begin{tabular}{|c|c|c|c|c|c|c|}
\hline No & EDS & $\begin{array}{l}\text { STATUS } \\
\text { GIZI }\end{array}$ & $\begin{array}{c}\text { PERKEMBANGAN } \\
\text { KEMLAMIPUAN } \\
\text { DASAR }\end{array}$ & $\begin{array}{c}\text { PERKEMBANGAN } \\
\text { KEMLAMUAN } \\
\text { DASAR }\end{array}$ & $\begin{array}{l}\text { STATUS } \\
\text { GIZI }\end{array}$ & EDS. \\
\hline & & & & $\mathrm{Y}$ & $\mathrm{X1}$ & $\mathrm{X} 2$ \\
\hline 1 & 6.00 & kurus & P & 1 & 1 & 6.00 \\
\hline 2 & 8.00 & normal & $\mathrm{S}$ & 2 & 2 & 8.00 \\
\hline 3 & 8.00 & normal & $\mathrm{s}$ & 2 & 2 & 8.00 \\
\hline 4 & 8.00 & normal & $\mathrm{s}$ & 2 & 2 & 8.00 \\
\hline 5 & 9.00 & normal & $\mathrm{s}$ & 2 & 2 & 9.00 \\
\hline 6 & 10.00 & normal & $\mathrm{s}$ & 2 & 2 & 10.00 \\
\hline 7 & 10.00 & kurus & $\mathrm{p}$ & 1 & 1 & 10.00 \\
\hline 8 & 13.00 & normal & $\mathrm{s}$ & 2 & 2 & 13.00 \\
\hline 9 & 13.00 & kurus & $\mathrm{p}$ & 1 & 1 & 13.00 \\
\hline 10 & 13.00 & normal & $\mathrm{s}$ & 2 & 2 & 13.00 \\
\hline 11 & 13.33 & kurus & $\mathrm{p}$ & 1 & 1 & 13.33 \\
\hline 12 & 13.50 & normal & $\mathrm{s}$ & 2 & 2 & 13.50 \\
\hline 13 & 14.00 & normal & $\mathrm{s}$ & 2 & 2 & 14.00 \\
\hline 14 & 15.00 & kurus & $\mathrm{p}$ & 1 & 1 & 15.00 \\
\hline 15 & 15.00 & normal & $\mathrm{s}$ & 2 & 2 & 15.00 \\
\hline 16 & 15.00 & normal & $\mathrm{s}$ & 2 & 2 & 15.00 \\
\hline 17 & 16.00 & normal & $\mathrm{s}$ & 2 & 2 & 16.00 \\
\hline 18 & 18.00 & normal & $\mathrm{s}$ & 2 & 2 & 18.00 \\
\hline 19 & 18.30 & kurus & $\mathrm{p}$ & 1 & 1 & 18.30 \\
\hline 20 & 18.75 & kurus & $\mathrm{p}$ & 1 & 1 & 18.75 \\
\hline 21 & 20.00 & normal & $\mathrm{s}$ & 2 & 2 & 20.00 \\
\hline 22 & 20.00 & normal & $\mathrm{s}$ & 2 & 2 & 20.00 \\
\hline 23 & 20.00 & normal & $\mathrm{s}$ & 2 & 2 & 20.00 \\
\hline 24 & 22.00 & normal & $\mathrm{s}$ & 2 & 2 & 22.00 \\
\hline 25 & 22.00 & normal & $\mathrm{s}$ & 2 & 2 & 22.00 \\
\hline 26 & 23.30 & normal & $\mathrm{s}$ & 2 & 2 & 23.30 \\
\hline 27 & 26.00 & normal & $\mathrm{s}$ & 2 & 2 & 26.00 \\
\hline 28 & 60.00 & normal & $\mathrm{s}$ & 2 & 2 & 60.00 \\
\hline
\end{tabular}

Keterangan: $\mathrm{S}=$ Sesuai, $\mathrm{P}=$ Menyimpang. 
Table 4. Kendall Coefficient of Concordance

\begin{tabular}{ccc}
\hline Sum of Ranks & Avg. Rank & \\
\hline 42.00 & 1.50 & Basic ability development \\
42.00 & 1.50 & Nutritional status \\
84.00 & 3.00 & EDS \\
168.00 & 2.00 & Total \\
& 28 & $\mathrm{~N}$ \\
& 56.000 & chi-square (corrected for \\
& 2 & ties) \\
& $6.91 \mathrm{E}-13$ & d.f. \\
& 1.000 & W \\
& 1.000 & avg. rank-order correlation \\
\hline
\end{tabular}

(1) as in the table below.

From statistic test result, it shows that the coefficient coefficient of Kendall $(\mathrm{W})=1.00$ is statistically significant with $\mathrm{Chi}$-square value $=56.00$ with $\mathrm{p}$ (value) $<0.01$. The conclusion is that there is a significant correlation $(\mathrm{W}=1.00)$ between the EDS variable and the dental status with the development of the KMK child's ability. This indicates that the development of KMK child's ability is closely related to nutritional status and EDS.

\section{DISCUSSION}

Intra Uterine Growth Restriction (IUGR) will cause the birth of a KMK baby. Disorders during this pregnancy will interfere with the growth of organs of children KMK, among others the development of enamel dentistry and development of the central nervous system.

The development of enamel begins at the prenatal period. The aposition phase characterized by the formation of a matrix secreted by ameloblasts and odontoblasts occurs at the end of the morphodifferentiation stage of the formation of primary teeth (11-12 prenatal weeks), and the calcification stage begins 12-23 weeks prenatal.11.18 The defect of the enamel of the deciduous teeth occurs when there is a disturbance in the growth and development of enamel. ${ }^{19}$ The extent of the defect depends on the intensity, duration and time of disturbance at the time of amelogenesis. ${ }^{19}$ The intensity, timing and duration of developmental discrepancy of the deciduous tooth will determine the severity of enamel dent defect. The longer and earlier the disturbance occurs the worse the EDS of the tooth begins. ${ }^{19}$

The development of the Central Nervous System (CNS) begins in the third week (day 16). The proliferation process lasts from 4 to 24 weeks prenatal. The process of migrating brain cells lasts approximately at 16 weeks prenatal until the end of the 6th month. At the end of the sixth month, nerve cells undergo differentiation processes (changes in shape, composition and function). The fastest brain growth occurs in the prenatal third trimester to 2 years postnatal. At this time there is a rapid division of brain cells, after which the division slows down and there is an enlargement of brain cells only. The rapid growth of brain tissue is a period of vulnerability, any disorder in this period will result in disturbance in the number of brain cells, so the number of brain cells decreases, which will affect the structure and function of the brain that will affect the intellectual child. ${ }^{8}$ Intensity, timing and duration of prenatal and postnatal impairment affect the child's brain development. The longer and premature the prenatal disorder the worse the child develops.

Seeing the same critical period between the development time of firstborn and CNS development, then if there is IUGR, then the two organs will be disrupted development.

The results of this study showed that the firstborn of KMK child had an email defect. The incidence of birth defects in tooth enamel in children KMK according to Willyanti (2009) amounted to $86.93 \%{ }^{7}$, and the results showed that there are children KMK the development of its ability accordingly and there are also deviations. The correlation between enamel defect and nutritional status with the development of KMK child's basic ability, either descriptively or statistically, shows a linkage.

Infant and toddler period is a very important period of life or also called a critical period, in this period there is a very rapid linear growth, which means in this period is a good opportunity to immediately fix the deviations found so that optimal growth can be achieved, ${ }^{21}$ because when the cause and delay of growth lasts longer, the child will never catch up. ${ }^{16}$ The effects of malnutrition vary with timing, so the effects of nutritional rehabilitation are also affected by time. When 
nutritional rehabilitation is done at the beginning, when cell division is occurring, then catch-up growth will occur. ${ }^{22}$ It is therefore important that rehabilitation is provided as early as possible and in the long term. Rehabilitation includes good nutrition and combined with environmental stimulation and emotional support. ${ }^{22}$

Nutrition is a body builder that has an influence on growth and development, especially in the first years of life where children are experiencing rapid growth, especially brain growth. Successful development of children is determined by the success of growth and brain development. Therefore, nutrition, in addition to affecting growth, also affects the development of the brain. ${ }^{3}$

Growth is an increase in body size, both physical (anatomical) and structures in a partial or whole sense. Growth in children is usually predictable and at present there are standard standards for use as a judging tool. ${ }^{21}$

Developments occur simultaneously with growth. The development is the result of the interaction of maturation of the central nervous system with the organs affected, including the development of neuromuscular, language, emotional and social systems. The growth and development of the postnatal child is influenced by, among other things, by nutrition. ${ }^{3}$ Provision of good nutrition so that the child's nutritional status becomes normal and done at the beginning when cell division is occurring, the catch-up growth will occur. ${ }^{22}$ According to Johnston (2004), is developing has the ability to adapt, adjust to change, this is called plasticity. This plasticity related to brain learning and plasticity also occurs in the process of repair of brain damage that occurs at an early age. $^{23}$

The important period in postnatal child growth is during infancy. The basic development that takes place in the under five years will affect and determine the development of the next child. Period after birth, especially in the first 2 years of life where growth and development of brain cells is still ongoing and there is growth of fibers of nerve fibers and branches, resulting in complex nerve and brain tissue. The number and arrangement of these relationships between nerve cells will greatly affect any brain performance, ranging from the ability to perform rough motor movements, fine motor, language, and social skills. ${ }^{24}$ The period of the first five years of life is a very sensitive period to the environment and this period is very short and can not be repeated again, the toddler period is called the "golden period", "window of opportunity" and "critical period"

The formation of enamel of the deciduous teeth occurs during the prenatal period, the disturbance in growth and development of enamel of the deciduous teeth will cause the enamel of the deciduous tooth defect. ${ }^{19}$ Email does not experience remodeling and resorption, meaning that if the email is damaged, then the damage is settled. ${ }^{10,25}$

The facts above explains that the development of basic capabilities of KMK children may remain appropriate, whereas their tooth enamel remains defective, although dental growth and growth of the central nervous system when prenatal are simultaneously subject to growth (IUGR).

\section{CONCLUSION}

There is correlation between enamel defect and the nutritional status with the development of KMK child ability. This indicates that the development of KMK child's ability is closely related to nutritional status and EDS.

\section{REFERENCES}

1. Anderson MS, Hay WW. Intrauterine Frowth Restriction and the small for gestational age infant dalam Avery GB, Fletcther MA, Mac Donald MG, penyunting. Neonatologi, pathophysiology and management of the newborn. Edisi ke-5. Philadelphia, 1999. H. 411-44

2. Battaglia F, Lubchenco L. A Practical classification of newborn infants by weight and gestational age. J pediatri. 1967; 71-159

3. Soetjiningsih. Tumbuh Kembang Anak dan Remaja. Edisi Pertama. Jakarta: CV. Sagung Seto. 1995.

4. Klaus MH, Fanaroff AA. Care of the high risk neonate. Edisi ke-4. Philadelphia: W.B. Sauders Co. 2003. H. 69-83.

5. Gomella TL, et al. Assessment of gestational age. Dalam Gomella TL., Cunningham D, 
Eyal FG, Zenk KE, penyunting. Neonatology, management, procedures, on-call problems, diseases, adn drugs. Edisi ke-5. Appleton\&Lange, 2004. H. 21-8,469.

6. Perinatologi RSUP dr. Hasan Sadikin: Laporan Tahunan Perinatologi 2005

7. Willyanti,S. Skor Prediksi Tingkat Keparahan Defek Email Gigi Sulung Pada Anak Dengan Kecil Masa Kehamilan. Unpad Press. 2009.

8. Narendra., M.B., dkk. . Tumbuh Kembang Anak dan Remaja. Edisi Pertama. Jakarta : CV. Sagung Seto. 2002.

9. Wikipedia. Diambil dari http://en.wikipedia. org/wiki/Small_for_gestational_age.

10. Balogh MB, Fehrenbach MJ. Dental Embryology, Histology and Anatomy. 2nd ed. St Louis: Elsevier Saunders. 2006.

11. Finn, S.B. Clinical Pedodontics. 4th ed. Philadelphia: W.B. Saunders Company. 2003.

12. Koch, G., Poulsen, S. Pediatric Dentistry : A Clinical Approach: Copenhagen : Munksgaard. 2001.

13. Avery, J.K., Chiego. D.J. Essentials of Oral Histology and Embryology: A Clinical Approach. 3rd ed. St Louis: Mosby Inc. 2006.

14. Rensburg, B.G.J.V. Oral Biology. Chicago: Quintessence Publishing Company. 2005.

15. Fadlyana, EPenilaian Pertumbuhan Pada Masa Bayi dan Balita. Diambil dari Kumpulan Naskah
Lengkap PIT IV IKA Medan 2010. Medan: Usu Press. 2010.

16. http://preemies.about.com/od/glossary/g/ CatchUpGrowth.htm

17. Argarwal KN, Faridi MMA, Kalra N. Deciduous dentition and enamel defects. India Pediatrics 2003; 40:124-9

18. Stewart, R.E. Pediatrics Dentistry. St Louis: The C.V. Mosby Company.1982.

19. Mc Donald, R.E., Avery D.RDentistry for the Child and adolescent. 6th ed. St Louis: The C.V. Mosby. 1994.

20. Gregor, MJ. Introduction to the Anatomy and Physiology of Children. 2nd ed. Abindong: Routledge. 2008.

21. Narendra., M.B., dkk. . Tumbuh Kembang Anak dan Remaja. Edisi Kedua. Jakarta : CV. Sagung Seto. 2002.

22. Gibson,K.R., Petersen,A.C. Brain Maturation and Cognitive Development. New York: Aldine de Gruyter. 1991.

23. Sadler, T.W. Embriologi Kedokteran Langman. Diterjemahkan oleh dr. Joko Suyono. Jakarta: Penerbit Buku Kedokteran EGC. 2000.

24. Johnston, M.V. Injury and plasticity in the developing brain. Experimental neurology. p184. 2003.

25. Simmer JP. Dental Enamel Formation and Is Impact on Clinical Dentistry. J Dent ed. 2001. 